Sara $M$. Butler

\title{
Women, Suicide, and the Jury in Later Medieval England
}

$\mathbf{n}$ the year 1397 in the parish of Tuttington (Norfolk), a woman whose name is lost to history, frantic to rid herself of the evil spirit that possessed her, turned to suicide. She attempted first to hang herself, but her husband discovered her while life remained in her body, cut down the rope, and comforted her. A few weeks later she tried once again to hang herself, but the rope broke. As soon as she had regained her breath, she raced to a nearby pond, reported to be at least six or seven feet deep, and leaped in with the aim of drowning herself, but even though her head submerged three times, she was not able to sink. She struggled out of the pond and walked to the home of her sister to tell her about the day's events. Her sister begged her to confess to the local priest, convinced that only through confession might she drive away the malevolent spirit. The sister then kindly put the woman to bed and rushed off to the woman's house for dry clothes to make her more comfortable. After her sister had departed, the woman decided to make one last attempt. She found a small dagger hanging on the wall of the cottage, and she stabbed herself three times in the stomach. Still she did not die. When she finally understood that the spirit was preventing her from taking her life, the woman tried to cut out her heart, assuming that her body could not live without it. The blade was insufficient for the task, however, and she had to settle for enlarging the original wound, pulling out her intestines, and strewing them about the room. By the time her sister arrived back with the parish priest in tow, the room had the appearance of a grisly murder scene, yet without a victim. The woman had been driven mad, rolling her flashing eyes about in her head. After he had overcome his initial shock, the priest assumed control of the room: he commanded the wild woman to think of God and to cast out her despair. He then urged her to confess her sins, promising her forgiveness; she did so, receiving a suitable penance and the viaticum. Only then was she able to find the peace she so des-

[Signs: Journal of Women in Culture and Society 2006, vol. 32, no. 1]

(C) 2006 by The University of Chicago. All rights reserved. 0097-9740/2006/3201-0001\$10.00

Monday Jun 122006 10:23 AM SIGNS v32n1 60022 PBW 
CHECKED 2 I Butler

perately sought. She lived three more hours, and then died, choosing

God's mercy (Shinners 1997, 221-22). ${ }^{1}$

This tale is drawn from the continuation of the Walsingham Chronicle, almost certainly written by William Wyntershylle in the fifteenth century (Shinners 1997, 220). Although it purports to be a record of recent events, the fantastic elements of the story indicate that it was reshaped into a more conventional morality tale, chock full of demons and evil spirits, precisely the kind of exemplum the medieval church embraced as a didactic tool to encourage good Christians to avoid sin and despair. In this gruesome account of a woman's ardent desire to end her life, the details are representative of the genre. Despair, madness, and demonic possession all combine to remind Christians that demons and spirits lurk behind every rock and that only perfect faith can save a person from the eternal torments of hell that surely would have awaited this woman if she had died unrepentant. Even the gender of the suicide was a fairly common representation. Long before the early modern witch craze, powerful associations between women and the devil enjoyed an enduring tradition in the iconography of the medieval church. Tracing the connection between women and the devil to the medieval interpretation of the story of the Fall, in which the serpent was often represented with a woman's face (at times even wearing a woman's bonnet and collar or sporting female breasts), Chiara Frugoni argues that the feminization of the devil on earth was ubiquitous in medieval art and literature. She declares that the correlation between woman and devil was "so commonplace at the time that the onlooker would have considered it perfectly natural for the devil to choose a member of the female sex as his favorite disguise" (Frugoni 1992, 350-51), a situation that Frugoni observes was, in fact, an essential element of a saint's biography. ${ }^{2}$ Eve's lack of reason, a legacy passed down to all women, meant that women in general were more easily drawn in by the deceits of the devil. H. C. Erik Midelfort has made a similar point, although he suggests that old age intensified the connection. $\mathrm{He}$ notes that "physicians, jurists and theologians all agreed . . . [that] in their weakness, loneliness, poverty, melancholy, and infidelity, suffering uncontrollable fantasies, and laboring under sexual frustrations, old women made easy victims for the devil" and thus were "more susceptible to demonic possession" (Midelfort 1999, 69). Barbara Newman (1998)

\footnotetext{
${ }^{1}$ For other examples of the possessed woman in sermon stories, see Strange (1851, 1: $26)$; Herbert $(1910,586$, no. 60$)$.

${ }^{2}$ See also Herbert 1910, 180, no. 13 and 459, no. 26; Gering 1882-83, 2:191; Aquiló y Fúster 1881, 141.
} 
also emphasizes the link between women and demonic possession. In her study of demoniacs in thirteenth-century Europe she observes that women were disproportionately represented among the possessed. She also makes it clear that possessed women played an important and visible role in later medieval society: not only were they ostensibly encouraged to preach publicly on Christian doctrine but they also used their newfound powers to discipline clerics and uphold communal values. Moreover, the medieval church accorded possessed women a measure of respect, going so far as to host public debates between demoniacs and members of the clergy.

The image of the possessed woman eventually driven to suicide by the malevolent urgings of her inner demons was a powerful one and familiar throughout the medieval world, but just how dominant an image was it when it came to dealing with actual cases of self-killing? When a coroner's jury came face-to-face with the bloated corpse of a woman drowned in a pond, did morality tales of this nature, lingering in the back of their minds, persuade them to form a judgment of suicide (i.e., a felonious self-killing) rather than accidental death (which would include a self-killing committed while non compos mentis) $?^{3}$ Here it is important to acknowledge that suicide (described in the criminal records as felo-de-se, or felony of self) stood out from most other felonies in this period as a crime of an exceptionally heinous nature. Not only were suicides denied burial in consecrated ground but also, it has been argued, popular practices encouraged a brutal and barbaric interment precisely to address the possibility of diabolical possession. It is thought that suicides were buried at a crossroads with a stake through the chest pinning the body to the ground-thus, if the demon did somehow manage to escape, at the very least, it might have difficulty finding the exact road to take back to the village (MacDonald and Murphy 1990, 18-19; Halliday 1996). Medieval jurors must have had these ideas in mind when determining verdicts in cases of selfkilling. Were medieval jurors more inclined to condemn female self-killers to a suicide's death because of the familiar figure of the mad, possessed woman?

In many ways this image of the morbidly violent woman runs counter to the perception of medieval felons drawn from the legal records. Historians of the law have argued repeatedly that medieval English women

\footnotetext{
${ }^{3}$ According to the legal treatises, English courts believed a person was non compos mentis (i.e., mentally incompetent and thus legally irresponsible) if he or she was a child, simple, or insane (either temporarily or permanently). A culpable individual is one who is capable of understanding the difference between right and wrong.
} 
CHECKED 4 I Butler

rarely engaged in violent acts. In her study of gaol delivery records for three English counties from 1300 to 1348, Barbara Hanawalt has argued that medieval grand juries rarely accused women of felonies; women appeared as suspects in only 10 percent of felonies (Hanawalt 1976, 115). In her study of women and crime in the courts of gaol delivery between the years 1388 and 1409, Kathleen Garay suggests an even smaller figure: she found one female suspect for every twenty-five men (thus, 4 percent) (Garay 1979, 89). Such a low rate of criminal activity for women was not peculiar to the medieval period; for years historians and sociologists alike have tried to explain the consistently low participation rate of women in violent crimes throughout history. Pitting biology against environment, scholars have tended to divide into two camps. First, women are less violent because their psychological drives are maternal and pacific, thus their instinctual makeup is not predisposed toward hostile or antisocial behavior (Bonger 1916, 64). Second, women are less violent because they are socially conditioned to be submissive and nonaggressive, a significantly more appealing argument to feminist historians who reject the wider implications of an explanation reliant on biological determinism (Pollak $1950,3)$. While both theories have their merits, as an overall rationale to explain the substantially lower numbers of women participating in violent crimes throughout history, neither is very satisfactory. In recent years a more agreeable hypothesis has emerged: the importance of chivalry and its place in the practice of the law. From this perspective, women do not necessarily commit fewer violent crimes than men do, but social expectation permits women to evade punishment for their crimes (McLane $1988,52-53)$. Women appear less frequently before courts of law because law enforcement officials rarely suspect them of being capable of violence and therefore often do not investigate the possibility of a female perpetrator. Even those women who stand accused of violent crimes receive far more lenient treatment at the hands of jurors than do men. A jury is more likely to acquit women of violent crimes for little reason other than that it is hard to imagine a woman capable of such aggression. Recent scholars of suicide in the medieval context have been won over by this standpoint. In the first tome of his ambitious three-part series on the subject of suicide, Alexander Murray has written that gender was an important consideration for juries in medieval England. Juries more frequently excused women of the crime because "female suicide was just too horrible to think about" (Murray 1998, 384-85). Thus many jurors chose instead a generous reinterpretation of female self-killing, reporting deaths of this nature as accidental deaths or acts committed while non compos mentis. The self-

Monday Jun 122006 10:23 AM SIGNS v32n1 60022 PBW 
killers were then permitted a Christian burial, and their lands were exempt from royal confiscation.

Here lies the crux of the issue. Were medieval jurors torn between these competing images of the mad, possessed woman driven to suicide, on the one hand, and the meek, well-mannered woman who spurned physical violence, on the other? If the former were the more dominant image, one might imagine jurors were more likely to condemn female self-killers to a suicide's death, to ensure the entrapment of the devil. Conversely, if the latter were the governing image, one would expect to find that women were frequently acquitted of the crime, their deaths declared accidental. The goal of this article is to determine which of these images held more sway among the jurors of medieval England when confronted with cases of female self-killing, with the broader aim of obtaining a clearer understanding of the perceived relationship between women, violence, and the devil. ${ }^{4}$ Jurors, as the male leaders of their localities, were chosen to represent communal values, thus, an analysis of their judgments should help us to clarify medieval perceptions of women and self-violence. This study investigated a corpus of 718 cases of self-killings drawn from all surviving coroners' rolls, two eyres per county, all criminal trial records for Essex (representative of the south) and York (representative of the north), and then all printed eyres, spanning the period from the thirteenth to the early sixteenth centuries. ${ }^{5}$ As many other historians before me have lamented, medieval records of indictment can be maddening in their lack of detail. Most include only the bare necessities, and rarely do they offer insight into the motivation of the perpetrator or the decision-making process of the jury. Nevertheless, this grouping of cases is capable of shedding some much-needed light on the role of women in self-violence in the Middle Ages. The first section of this article will address the statistics of female self-killers: How frequently did medieval jurors report female self-killers, compared to male self-killers, and were there gendered differences? The second section will speak to medieval jurors and the quality of their mercy,

\footnotetext{
${ }^{4}$ This study defines self-killing simply as any death brought about by the defendant's own hand. Not all self-killings were declared by jurors to be suicides (felonious self-killings). Jurors declared others to be deaths by misadventures (accidental deaths), some of which were actually deliberate self-killings yet excused on the grounds that they were committed while non compos mentis.

${ }^{5}$ For information on sources consulted for this study but not directly cited in the text, please see the appendix. An eyre court is the meeting of an iterant royal justice with juries chosen from the community, with the intention of trying all accused criminals held in the local prison.
} 
CHECKED 6 I Butler

attempting to discover which image, that of the possessed or docile woman, was more dominant. The final section will turn to the more typical verdict handed down by jurors in an attempt to answer whether jurors were more or less inclined to see female self-killers as deserving of harsh verdicts.

\section{Gender and visibility in suicide totals}

Prompted by what appears to have been an exponential leap in suicide rates during the early modern period and continuing to the present day, scholars have argued widely that "what has changed markedly [since the Middle Ages] is the incidence of concealment," not the rate of suicide itself (Hair 1971, 16). It is crucial to recognize that the underreporting of suicide may have been a recurrent problem in the medieval era; thus, the legal records cannot present the entire picture of suicide rates and practices. This hypothesis, however, implies a pervasive sense of compassion for self-killers, one that does not necessarily conform to the outcomes of cases addressed in the medieval English courts. Contrary to earlier assumptions that medieval jurors were predisposed to merciful verdicts out of pity for the financial well-being of the dead's family (MacDonald and Murphy 1990, 16), the figures demonstrate that the prosecution of suicides was harsh in medieval England. Of the 718 cases of self-killing examined in this study, 78.7 percent (or 565 out of the 718 cases) were declared suicides (thus, felonious self-killings) in either the narrative or marginalia (the remainder were declared deaths by misadventure, some purely accidental, and others non compos mentis). At a time when acquittal rates for felony in general hovered around 65 percent (Musson 1996, 211), this figure for suicide "convictions," although not a direct comparison, is astonishingly high. Those cases of self-killing reported to the courts, then, may well represent those cases determined by their communities to be the most egregious examples of self-killing, in need of intervention by a higher authority.

An examination of the cases themselves demonstrates a much higher visibility and accountability of women for self-inflicted deaths than many have previously imagined. Of the 718 cases of self-killing appearing in the coroners', eyre, and assize rolls, 464 were committed by men, 253 by women. ${ }^{6}$ Thus women were thought to have committed roughly 35 per-

\footnotetext{
${ }^{6}$ In one case, the accused is of unknown gender. Unfortunately, the perpetrator's name was torn off, and the manuscript is in terrible condition. See The National Archives (TNA) JUST 1/1078, ms. 45 (Yorkshire), death of . . . of Ravensworth in Ainderby.
} 
cent of the total number of self-killings. When juxtaposed against those figures for the participation of women in felonies drawn from the studies of Hanawalt (1976) and Garay (1979), this figure is instructive. Although in a minority at only 35 percent, women still made up a drastically higher percentage of those convicted for self-killings than for any other felony. Thus, the records offer us two possible conclusions: first, that a woman was more likely to commit suicide than engage in any other felony (see Butler 2006); second, that jurors were more willing to accuse a woman of suicide than of any other felony. Once again, it is important to point out that jurors could easily have reinterpreted or deliberately misunderstood many cases of female suicide if the thought of a woman taking her own life had been so utterly scandalous to them. While the 130 deaths of women by hanging may have compelled coroners' jurors to confront a stark reality, at least eighty-seven female deaths by drowning and three by house burning could easily have been regarded as deaths by misadventure.

English men and women participated in suicide in distinct ways, although not necessarily as historians have traditionally supposed. In 1970, P. E. Hair declared in an oft-quoted statement, "for the worn-out and sickly Tudor housewife, the well appears to have been the equivalent of the twentieth-century gas-oven-the domestic chore whose lethal misuse offers release" (Hair 1970, 42). An examination of the cases of self-killing suggests that jurors did not see drowning as a quintessentially female method of suicide. While 34 percent of female self-killers died by drowning, 29 percent of male self-killers chose the same method. Women were also more likely to die by hanging: 51 percent of female self-killers chose this route compared with 41 percent of male self-killers. In fact, if we were to choose a typically feminine method of death, hanging with a wimple, the traditional medieval woman's cloth headdress, would seem more fitting. ${ }^{\text {? }}$

Where the difference between genders is most apparent is in those cases of death by stabbing or wounding with a sharp tool (knife, ax, fork, razor, or arrow). Women employed this method in 8 percent of self-killings; men employed it in 22 percent of self-killings. Not only is this the most painful way to commit suicide because of the prolonged nature of the

\footnotetext{
${ }^{7}$ For a few examples, see TNA JUST 1/461, ms. 34 (Leicestershire), Adthelina Woderone; TNA JUST 1/568, ms. 31 (Norfolk), Olivia wife of Robert Parson; TNA JUST 1/ 683, ms. 28 (Nottinghamshire), Alice wife of Robert de Bole; TNA JUST 1/1022, PART 2, ms. 32 (Worcestershire), Christiana daughter of Alan of Wendale; Harding 1981, 197, no. 487 , Douce wife of Llewellyn.
} 
CHECKED 8 I Butler

death, it is also one of the most bloody and dramatic forms of suicide. Men appear to have been drawn more frequently to dramatic deaths than were women. In fact, those suicides whose deaths were especially shocking or gruesome were usually male. By far the most dramatic death would have to be that of John the Welshman of Lincolnshire who in the year 1364 sliced off his penis and testicles and then slowly bled to death. ${ }^{8}$ Even the more mundane self-killings by men were sometimes carried out in grisly ways. In January of 1391 Thomas Nulleward of Staffordshire died by throwing himself into the cogs of a mill where he was crushed to death. ${ }^{9}$ When Thomas Warner of Moulton (Lincolnshire) drowned himself in the year 1365, he tied both his hands and feet first; when William le Mere of Ashby (Northamptonshire) drowned himself, he tied one end of a rope around his neck and the other around a rock before jumping into a marl pit. ${ }^{10}$ Male suicides were also far more frequently recorded as having slit their throats, an especially horrific and gory form of suicide. In opposition, only two cases of female self-killing evince a measure of the macabre. In May of 1286 Agnes Page of Northamptonshire killed herself in a theatrical and seemingly male fashion: she slit her stomach and pulled out her intestines; she died five days later. ${ }^{11}$ The other case is more typically feminine: in June of 1316, suffering from frenzy, Emma le Bere slit the throats of four of her children with an ax before hanging herself (Hunnisett $1960,114)$. While certainly gruesome, the shock value of this case is lessened in part because of her gender. To hear of a crazed woman killing her children and then herself, even in the Middle Ages, was not an entirely shocking event. ${ }^{12}$ Hanawalt's early work demonstrates that if a woman was going to kill anyone, it was most likely going to be a member of her own family (1976, 130-31). Even the miracle stories distributed by the church in this period suggest that medieval men and women may have understood the existence of postpartum depression, although it was understood from a much less psychological perspective than it is today. The twelfth-century Cistercian monk Caesarius of Heisterbach, in his Dialogus miraculorum, tells the story of a young mother who was driven to suicide by the urgings of Satan. She promises a close friend, a monk, that she will wait two weeks before carrying out the act, until he is able to visit

\footnotetext{
${ }^{8}$ TNA JUST $2 / 67$, ms. 28 (Lincolnshire).

9 TNA JUST 2/164, ms. 4 (Staffordshire).

10 TNA JUST 2/67, ms. 26d (Lincolnshire); TNA JUST 1/635, ms. 42 (Northamptonshire).

11 TNA JUST $1 / 635$, ms. 24 (Northamptonshire).

12 The image of the suicidal murdering mother appears in other sermon stories (Herbert 1910,549 , no. 119; 677, no. 15; 381, no. 134; 482, no. 39; Klapper 1914, 106).
} 
her. During his visit he takes her confession, asks her what method of suicide she would prefer, then commands her to hang herself as penance for her sins; at this point the woman breaks down crying, pleading with the monk that she wishes to live. The story draws to a conclusion by assuring the reader that although the young mother went on to have more children she was never bothered by the devil again (Caesarius of Heisterbach 1901, 2.33, 111-13; Newman 1998, 747-78). In her study of postpregnancy purification rituals Paula $M$. Rieder has also argued that it was a common belief that "childbirth made a woman especially vulnerable to [demonic] possession" $(2002,101)$. Certainly there is good reason to believe, then, that the image of a suicidal or violent young mother may have been common enough that jurors would not have been shocked by the death of Emma le Bere.

\section{Gendered compassion}

Despite the horror most jurors seem to have felt when confronted with a self-killing, at the same time they could be capable of great sympathy. Taken to the extreme, compassion might extend to the point of pronouncing instantly recognizable cases of suicide as deaths by misadventure. For example, in thirty cases of suicide by hanging, jurors issued judgments of misadventure. ${ }^{13} \mathrm{~A}$ jury's declaration of misadventure in a case of drowning is credible; in a case of hanging it is hard to see the jury's decision as anything other than a polite fiction out of pity for the dead and his or her family. In these circumstances jurors do not seem to have been any more or less considerate of female suicides than of male. ${ }^{14}$ At other times, however, gender may have determined this sense of clemency. It is striking that those cases described most sympathetically in the rolls were all cases of female suicide. For example, a Cambridgeshire coroner's roll recounts a case from the year 1372 when Ellen wife of Thomas the clerk of Barnwell, dressed only in her underwear, walked to the river, where she drowned herself. The record notes, however, that at that time she was out of her senses because of the great sorrow that she held for her son. The trial jury's verdict recorded in the margin was simply that she drowned herself,

${ }^{13}$ For example, see TNA JUST 2/21, ms. 9 (Cambridgeshire), Matilda Poncho; TNA JUST 2/67, ms. 33 (Lincolnshire), Alice wife of Robert Palmer; TNA JUST 2/74, ms. 7d (Lincolnshire), Joanna daughter of John Hetit of Milton; TNA JUST 1/488, ms. 20d (Lincolnshire), Matilda Budding of Belton.

${ }^{14}$ Fifteen cases of male hangings were described in this way; fifteen cases of female hangings were also described as accidents. 
CHECKED 10 I Butler

but nowhere does the narrative or marginalia declare that she was a felon. ${ }^{15}$ Similarly, in May of 1365 when Leticia wife of Simon Grindok de Necton walked to a nearby forest where she stabbed herself in the stomach, dying soon after, the coroner's roll describes her as having suffered from such great sadness that she lacked a sane mind. ${ }^{16}$ When Julianne wife of Gilbert Cotene lost her husband, Gilbert, in a fire, she followed her husband to the grave, voluntarily drowning herself in the river. Nowhere does the indictment state that the jury judged her actions felonious. ${ }^{17}$ All three of these cases are composed in a way that even today cannot fail to elicit sympathy from the reader. While trial jurors handing down their verdicts may not always have agreed, it seems clear that the poignant tales of these tragic deaths were designed to play on the heartstrings of friends, neighbors, and others in the community. These cases also indicate that jurors found female self-killers most sympathetic as mothers and wives, thus contradicting earlier assertions by Darrel Amundsen, who argued that for a woman suicide was acceptable only when a woman's honor was endangered by the possibility of sexual assault (Amundsen 1989, 78)..$^{18}$

A degree of compassion for the "gentler sex" is also evident in judgments of insanity. A jury's decision to describe a suicide as being mentally incompetent, or non compos mentis, is a crucial one in many ways. A self-killer who was non compos mentis was not held responsible for his or her actions and thus could be buried in consecrated ground and the family retain the self-killer's land and chattels that otherwise would have been forfeit to the king for a year and a day, just like those of any other felon. For a jury to describe some self-killings as felonies and others as acts of madness suggests the existence of an initial sorting process, dividing those deserving of sympathy from those who are not. It is striking that jurors favored women with a degree of mercy in this respect. Of the 105 self-killings described as having been the product of insanity, the rolls note that women committed forty-four (thus, 42 percent of the total cases of insane self-killings), while men committed sixty-one (or 58 percent of the total cases of insane self-killings). Because more men than women were self-killers, it is critical to consider these figures against the overall percentages of female versus male self-killers. The total number of female self-killers whose deaths were justified on the grounds of insanity is 17

\footnotetext{
15 TNA JUST 2/23, ms. 3 (Cambridgeshire).

16 TNA JUST 2/104, ms. 44 (Norfolk).

17 TNA JUST $2 / 111$, ms. 15d (Northamptonshire).

${ }^{18}$ I did not uncover any cases of this nature in the records.
} 
percent; for male self-killers the total number is 13 percent. Not only were juries more inclined to explain away women's self-killings as insane acts but they also seem to excuse female self-killings at a higher ratio than women-committed self-killings ( 1.32 women to every man, compared with 1 woman to 1.83 men). Overall, we are left with the impression that jurors were noticeably more determined to grant clemency to female self-killers.

Although contrary to the legal prescription, it was not unusual for jurors to describe an act as having been simultaneously insane and felonious, thus holding the suicide accountable financially and spiritually despite his or her mental state. Preliminary research into this field suggests that jurors imposed communal values of culpability where self-killing was concerned and may have even had a more nuanced understanding of the gradations of insanity than previously imagined (Butler 2006). Yet even in these cases jurors were less likely to hold a madwoman responsible for her actions. Eleven percent of the total number of female self-killers (or 27 out of 253) managed to escape a charge of felony on the grounds of insanity; only 8 percent of the total number of male self-killers (or 36 out of 464) merited the same fate. Once again, the disparity in totals is not very substantial; however, this deviation may give voice to a somewhat chivalrous approach among jurors who may have believed female self-killings were more excusable.

What is perhaps most surprising about the evidence of mad self-killers is the infrequency with which jurors reported demonic possession as a factor. Jurors reported only fourteen cases of self-killings caused by diabolical intervention. It is striking, however, that among those fourteen indictments nine of the self-killers were female and only five were male. ${ }^{19}$ With such an imbalance in the gender ratio, in the direct reverse of the overall gender ratio of self-killers, a tentative argument, one that accords well with the literary image of women, is that jurors believed the devil

19 TNA JUST 2/58, ms. 8d (Leicestershire), John Scot; TNA JUST 2/64, ms. 4 (Lincolnshire), Ralph de Newkirke of Stamford; JUST 2/159, ms. 1 (Staffordshire), Nicholas son of William Godwine; TNA JUST 2/215, ms. 4d (Yorkshire), John Milner of Fishergate; TNA JUST $2 / 211$, ms. 18d (Yorkshire), Stephen; TNA JUST 2/59, ms. 3 (Leicestershire), Joanna wife of William Styward of Bosworth; TNA JUST 2/57, ms. 23 (Lincolnshire), Agnes de Goyton; TNA JUST 2/96, ms. ld (Middlesex), Marion wife of Simon Rat of Ryslip; TNA JUST 2/104, ms. 17 (Norfolk), Agnes de Kirketon; TNA JUST 1/683, ms. 62d (Nottinghamshire), Alice who was the wife of William de Aston of Normanton; TNA JUST 2/138, ms. 5 (Oxfordshire), Katherine wife of Nicholas Pew; TNA JUST 2/146, ms. $5 \mathrm{~d}$ (Shropshire), Alice daughter of John son of John of Grenehill; TNA JUST $2 / 215$, mms. 3 and 4 (Yorkshire), Alice wife of John Horner; TNA JUST 2/221, ms. 2 (Yorkshire), Maud wife of Thomas of Rothwell. 
CHECKED 12 I Butler

primarily afflicted female self-killers. Further, the descriptions in the rolls themselves are intriguing. While the cases of male self-killings were invariably reported as having been through the temptation of the devil or at the instigation of the devil, the reports for female self-killers tended to be more creative. For example, in 1364 when Matilda wife of Thomas of Rothwell of Yorkshire struck herself with a knife in the stomach and the chest, then confessed before dying, she is said to have done so "through the temptation of an evil spirit and out of felony." ${ }^{20}$ In 1361, when Agnes de Goyton of Lincolnshire, "aged forty years and more," hanged herself by a rope in her home, she is said to have done so "not having stable faith, and vexed by a demon, not having memory of, nor faith in, the Lord." ${ }^{21}$ The only clear case of possession (as opposed to diabolical harassment) was reported by Nottinghamshire jurors, who noted that Alice wife of William de Aston of Normanton was "possessed by a demon" when she voluntarily submersed herself in the River Soar in $1329 .{ }^{22} \mathrm{Fa}-$ miliarity with this theme from literature and art may have supplied bewildered jurors with a ready-made explanation for a woman's suicide. As much of the didactic literature disseminated by the medieval church would seem to suggest, women quite simply were more vulnerable than were men to the devil's lure (Gregg 1997). At the same time, the records show that jurors were most concerned about possessed women. Despite the logical conclusion that the defendant could not have been acting with a sane mind if possessed by the devil, allegations of diabolical incitement were not always sufficient grounds for a non compos mentis plea. Jurors declared six of these female self-killers to be felons; only one male met the same fate.

Despite Henry Summerson's assertion that, in terms of chattels, "female suicides were treated no differently than males," gender also seems to have been a central concern in the compassionate disposition of chattels (Summerson 2000, 20). While a suicide's chattels were normally forfeit to the king (except in those cases where a final judgment of non compos mentis was accepted by the court), at times both royal officials and jurors exhibited a distinct reluctance to carry out confiscation. For example, an assize roll from London describes a woman named only as Joan as having been mad when she drowned herself, stating that "she was in such a state that she could not forfeit [her] chattels because of her illness." The sheriff subsequently ordered that the "chattels should be given in alms for the soul of the same Joan, and the king would concern himself no more with

\footnotetext{
20 TNA JUST $2 / 221$, ms. 2 (Yorkshire).

${ }^{21}$ TNA JUST $2 / 67$, ms. 23 (Lincolnshire).

${ }^{22}$ TNA JUST $1 / 683$, ms. 62d (Nottinghamshire).
} 
those chattels" (Cam 1968, 93). This is an unusual situation. If a suicide was excused from his or her crime due to mental incompetence, court officials had no right to direct the disposal of that suicide's chattels without consulting first with his or her beneficiary, and there is no suggestion in the record that they did so. Joan's case must have been amply disturbing for the sheriff to buck tradition and instead concern himself with her soul.

More generally, the apprehension jurors had with royal forfeiture was that the loss of a suicide's lands and chattels for a year and a day would serve only to penalize the family of the dead; such a penalty may sometimes have seemed inappropriate. In the case of the suicide of a married woman, for example, jurors on occasion reported that the dead "had no chattels because she has a husband." ${ }^{23}$ Under the law married women owned no property; the rules of coverture clung to a legal fiction of husband and wife as one flesh represented by the husband. Nonetheless, in cases of suicide royal officials generally disregarded coverture; thus many married female suicides had their goods confiscated. ${ }^{24}$ The scolding of one particular coroner attests that it was not the usual course to spare a married man for his wife's suicide: when a Westmorland coroner failed to appraise the chattels in the suicide of Cecilia wife of Walter the manservant of Gilbert, the coroner was fined. ${ }^{25}$ In those cases where jurors took pity on married men, we may well be encountering an all-male jury caught between legal prescription and personal conviction: Should the king expect a householder to lose his joint property and find himself incapable of supporting his family when the law considered him to be the breadwinner?

Jurors also expressed a distinct anxiety about the families of male suicides. The suicide of a householder must have thrust many families into destitution in this period, making them a burden on their communities

${ }^{23}$ TNA JUST $1 / 242$, ms. 67d (Essex), Margery wife of Robert atte Berie; TNA JUST 1/242, ms. 102 (Essex), Christiana daughter of Simon de la Pyke; TNA JUST 1/278, ms. 47 (Gloucestershire), Matilda wife of Ralph le Neweman of Didbrook; TNA JUST 1/409, ms. 6 (Lancashire), Christiana wife of Robert son of Barnaby of Oldham; TNA JUST 1/ 409, ms. 32 (Lancashire), Margery who was the wife of Peter de Burhyl; TNA JUST 1/ 488, ms. 1ld (Lincolnshire), Alice wife of Thomas de Elvestok; TNA JUST 1/683, ms. 49 (Nottinghamshire), Alice Gene who was the wife of Robert Godelark of Kirkby; TNA JUST 1/705, ms. 6 (Oxfordshire), Agatha wife of William Steg of Hook Norton; TNA JUST 1/ 705, ms. 12d (Oxfordshire), Joanna wife of Adam de Munforteys; TNA JUST 1/1005, pt. 2, ms. 136d (Wiltshire), Edith wife of William Robert.

${ }^{24}$ For example, see TNA JUST 2/9, ms. 1 (Berkshire), Margaret wife of Richard Perot; TNA JUST $2 / 113$, ms. 8 (Northamptonshire), Agnes the wife of John the smith's son of Middleton; TNA JUST 2/214, ms. 6 (Yorkshire), Olivia wife of John Pickburn.

${ }^{25}$ TNA JUST $1 / 986$, ms. 8 (Westmorland). 
CHECKED 14 I Butler

and parishes. In at least one case royal officials made clear their empathy with the families of suicide. In the death of Nicholas son of John of Rufford, who reportedly killed himself while in a fury, a mandate from the king demanded that the chattels be given to Emma, the wife of the said Nicholas, to sustain herself and her children. ${ }^{26}$ When the king's officials were not inclined to compassion, jurors were prepared to submit false appraisals of the goods and chattels of a felon to the court in an effort to spare the family (Seabourne and Seabourne 2000, 36). In 103 instances, officials of the court scolded jurors after an investigation revealed that they had undervalued the goods and chattels of suicides. In seventy-seven of these instances, the self-killer was a man. Because of the nature of the records it is not possible to determine whether all seventyseven of these self-killers were married and supporting families-because marriage was such a highly significant rite of passage for men in which men became householders, it seems likely than many, if not most, were married. Hence, such a high incidence of false appraisals in male suicides implies that jurors sympathized with the wife and children of suicides whose loss was not only emotional but also financial.

\section{Women and harsh verdicts}

As the figures would suggest, where suicide was concerned medieval jurors were more inclined to severity than compassion, dedicated to judging selfkillers as suicides (i.e., felons) and thus sane, culpable beings. At times, coroners and grand jurors, at the forefront of the legal process, deliberately phrased indictments with the purpose of communicating their censure to the trial jury and thus of preventing trial jurors, who issued the final verdict in the case, from experiencing any last-minute compassion (Green 1985, $58)$. By including what John G. Bellamy has termed "phrases of afforcement" $(1998,29)$, jurors in the early stages of the process constructed indictments designed to emphasize the stealthy and private nature of the crime and thus to warn trial jurors that the self-killer merited a verdict of felo-de-se. In cases of self-killing, such terms might include "by night" (noctanter, ex media nocte, or some other variant); "murder" (murdravit); "with malice aforethought" (per malicia precogitata); "behind closed doors" (in domo sua clauso hostia); and "alone" (sola existens). For example, a case from a Yorkshire coroner's roll from 1354 recounts the death of Maud wife of Thomas of Rothwell of Totenay, discussed above.

${ }^{26}$ TNA JUST 1/409, ms. 11 (Lancashire). 
The indictment reports that "by night, alone and without any companion in the home of the said Thomas before the hour of the middle of the night, by the temptation of evil spirits and out of felony she struck herself with a knife in the stomach and again in the chest and afterwards confessed and she lived until the hour of vespers and then she died. No one was present or is suspected of the death." ${ }^{27}$ At a time when most men and women were engaged in what one historian has termed a "frustrated quest for privacy" (Ellis 1998, 196), it is hard to imagine that anyone would be capable of carrying out such a stealthy act. ${ }^{28}$ Jurors may have intended their emphasis on the private nature of Maud's self-killing to make certain that no one else would fall under suspicion for her death. However, the repetitive use of loaded terminology suggests that Maud was a woman whom jurors considered deserving of a harsh verdict.

In most cases the brevity and formulaic nature of the records make it impossible to explain the jury's motive in employing phrases of afforcement. Why a jury felt the need to describe Maud wife of John Chenyon's hanging as an event that occurred behind closed doors with felony an aforethought while the hanging of William Pleshly was described more succinctly as spontaneous and voluntary is simply not clear from the records. ${ }^{29}$ Perhaps Maud was the kind of woman whom her community deemed capable of great sin: an unrepentant scold, a disrupter of the peace, a petty thief, or a slanderer. The record of her sad death conveys none of this. Her gender, however, may have influenced the jury's judgment. It is striking that almost half (eighteen out of forty) of the cases that include phrases of afforcement in the coroners' rolls, where such phrases tend to predominate, relate to female suicides. ${ }^{30}$ Given that women constitute roughly 35 percent of self-killings, it seems clear that jurors employed phrases of afforcement disproportionately in cases of female suicide. While women were less likely than were men to commit suicide, they had a greater chance of suffering hostile treatment at the hands of coroner's jurors. This finding is not entirely surprising. In his study of fourteenth-century trailbaston records, B. W. McLane notes that jurors

27 TNA JUST 2/221, ms. 2 (Yorkshire).

28 The fact that some suicides were carried out in apparently populated areas, with family and friends as witnesses (rather than accomplices), reveals that absolute privacy was not easily achieved. See, e.g., TNA JUST 1/568, ms. 7 (Norfolk), death of Richard of Feltwell.

${ }^{29}$ On Maud wife of John Cheyon, see TNA JUST 2/18, ms. 4d (Cambridgeshire); on William Peshley, see TNA JUST 2/33a, ms. 15d (Essex).

${ }^{30}$ Compare this to eyre rolls: of the thirty-two cases employing phrases of afforcement, nine were female suicides, twenty-three were male. 
CHECKED 16 I Butler

were more likely to prosecute women as felons than they were to charge them with petty offenses. ${ }^{31} \mathrm{He}$ posits that communities tended to pursue women's misdeeds informally and that they brought female offenders before the royal courts only when they committed major crimes like homicide or felonious thefts $(1988,52-53)$. McLane's findings indicate that jurors-always male-viewed female felons in a harsher light, a reflection of their belief that criminal behavior was unfeminine; thus, any woman who engaged in such violent activities had failed to live up to the expectations for her sex.

One case in particular stands out from the rest and may help us to explain why jurors felt it necessary to underscore the egregious nature of an offense. A coroner's roll from Nottinghamshire dated 1503 recounts the story of Joan Wynspere of Basford, a pregnant "syngilwoman" who consumed a diversity of pharmaceutical drafts in the hopes of expelling the fetus from her womb and accidentally killed herself in the process. Rather than describe her act as a case of abortion, as one would expect for this period, a coroner's inquest jury chose instead to note that, "she feloniously slew and poisoned herself and also the child in her womb" (Hunnisett 1969, 8). Wynspere's case is an oddity. Contemporary legal thought held that her act of abortion made her a felon, but it is highly unlikely that a court would have treated her as one. As John M. Riddle notes, historians have to date uncovered no cases of self-inflicted abortion in the records of the medieval common-law courts (Riddle 1997, 91-125). In other respects, however, Wynspere did not really conform to the definition of a felonious self-killer; as the record itself reports, her death was an unexpected consequence of the abortion. More likely than not, the jury's decision to treat her as a felon expresses communal antipathy toward loose women, illegitimate pregnancies, and illicit abortions.

The jury's reaction to Wynspere's death may also have reflected her status as a single woman. As recent research by Sharon Farmer demonstrates, "prevailing cultural constructs" of the Middle Ages "rendered most singlewomen invisible or undesirable." In particular, "clerics were willing to acknowledge the existence of singlewomen only insofar as they could press them into the mold of Eve the seductress, whose existence could be tolerated only if she was clearly under the authority of a man" (Farmer 1999, 95). In her study of social misbehavior in late medieval and early modern England, Marjorie McIntosh also observed a distinct

31 A trailbaston was a special commission of justices appointed by the king to punish felonies and trespass at the king's suit. 
anxiety about single women. She groups single women with young people, outsiders, and the poor as the leading triggers of social regulation in this period (McIntosh 1998, 191). Popular antagonism largely discouraged single women from enjoying an independent lifestyle, and prostitution and begging seem to have been the unfortunate fate of many never-married women in the later Middle Ages (Karras 1999, 34; Farmer 2002, 23). A reproachful attitude may also help to explain why women are so disproportionately represented in indictments of self-killings. Because medieval records often identify women by their relationship with a man, judicial rolls can provide a rough guide to marital status. According to those examined here, 54 percent (or 136 out of 253 cases) of female suicides were married (either presently or at one time), 46 percent (or 117 out of 253 cases) were not. ${ }^{32}$ In the former category, it is possible that 35 percent (or 47 out of 136 cases) of those married were in fact widows, although it is not possible to confirm this positively. The difficulty lies in the identifiers: a woman described as Agnes who was the wife of Peter Sutor may have been a widow; however, use of the past tense may also have been the scribe's way of noting her passing. ${ }^{33}$ If all those cases of possible widows were in fact widows, single women would seem to dominate female self-killings at 65 percent (or 164 out of 253 cases). Because marriage was considered a career for most women, single women constituted a small percentage of the medieval population, thus it is remarkable that they should have appeared so frequently in suicide indictments. Indeed, single women may have been driven more commonly to suicide by financial instability, alienation, and communal censure. It is also possible that jurors, although often inclined to turn a blind eye to self-killings, allowed the marital status of the perpetrator, especially where women were concerned, to influence their decisions. Therefore, married women, who enjoyed the respect of the community by conforming to social expectation, may have escaped

${ }^{32}$ For the purposes of this study, I have looked at the identifiers for female self-killers (i.e., Alice wife of John Smith vs. Alice daughter of John Smith), as well as a number of other features. Occasionally, the record does not identify a woman by her husband, but he makes an appearance in the narrative as either a first finder or a bystander. I have also made the somewhat problematic assumption that a woman is or was married if a roll reports her as having children old enough to act as the first finder.

${ }^{33}$ TNA JUST 1/63, ms. 43d (Buckinghamshire). In some cases, these women were definitely widows. For example, see TNA JUST $2 / 85$, ms. 8 (Lincolnshire), in which the case of Christiana who was the wife of Roger Walker of Manthorp refers specifically to her husband's executor. 
condemnation and had their self-killings declared misadventures. Disapproving of the lives led by single women, jurors may have been more inclined to report their self-killings as suicides.

Condemnation of female self-killers may also have been regionally determined. An examination of the total numbers broken down by county and gender (see table 1 below) suggests that jurors in some counties were more prepared than others to resort to judgments of selfkilling when confronted with female corpses. Here it should be reiterated that this study does not attempt to present a comprehensive examination of all records from the period. As a result, the findings below do not represent actual rates of self-killing for the period but rather a sampling from each county. The focus, then, should be on gender ratios as opposed to an overall comparison on a county-by-county basis.

For most counties, the male-to-female ratio is balanced in favor of male self-killings, with female self-killings remaining quite low, as one might expect. What is interesting is those counties where female self-killings either surpass male self-killings (Berkshire, Nottinghamshire, and Southampton), or are roughly balanced (as is the case for Norfolk or Northamptonshire). If female self-killings usually constituted only a third of all reported self-killings, for some counties to report self-killings in equal numbers (or close to it) for both genders is significant and suggests that they were more willing to see women as being capable of such an act. Nottinghamshire, Norfolk, and Northamptonshire, three counties closely located in the East Midlands, all present substantial numbers of self-killings, of which female self-killers were thought to play an important role. Why the East Midlands? Why were jurors in this region more inclined to report cases of female self-killing than elsewhere? Here it may be prudent to return once more to McIntosh's study of social misbehavior at the end of the medieval period. McIntosh argues that later medieval England became progressively more intolerant of individuals who threatened the tight grip of social superiors on their communities and that this trend intensified in the early modern era with renewed vitality at the hands of the Puritans. McIntosh traces this pattern by examining cases of social disharmony (scolding, eavesdropping, etc.) and social disorder (sexual misbehaviors, persons without appropriate governance, etc.). By the sixteenth century most of England eagerly participated in this culture of social control; in the late medieval period, however, some regions were swifter to take part than were others. For the earlier part of the era, McIntosh's study suggests that the East Midlands, among other regions, played an important role in the regulation of social misbehaviors (McIntosh 1998, 173-74). Although on the surface suicide may not appear 
S I G N S Autumn 2006 | CHECKED 19

Table 1. Self-Killers by County

\begin{tabular}{|c|c|c|}
\hline County & Male Self-Killers & Female Self-Killers \\
\hline Bedford & 7 & 5 \\
\hline Berkshire & 4 & 5 \\
\hline Buckinghamshire & 3 & 1 \\
\hline Cambridge & 19 & 10 \\
\hline Cornwall & 8 & 4 \\
\hline Cumberland & 4 & 1 \\
\hline Derby & 10 & 3 \\
\hline Dorset & 9 & 2 \\
\hline Durham & 2 & 1 \\
\hline Essex & 22 & 8 \\
\hline Gloucester & 9 & 7 \\
\hline Hampshire & 12 & 2 \\
\hline Hereford & 4 & 3 \\
\hline Hertfordshire & 4 & 0 \\
\hline Huntingdonshire & 8 & 1 \\
\hline Kent & 23 & 13 \\
\hline Lancashire & 7 & 6 \\
\hline Leicester & 11 & 6 \\
\hline Lincoln & 29 & 14 \\
\hline London & 8 & 5 \\
\hline Middlesex & 9 & 1 \\
\hline Norfolk & 15 & 15 \\
\hline Northamptonshire & 22 & 21 \\
\hline Northumberland & 13 & 5 \\
\hline Nottinghamshire & 17 & 19 \\
\hline Oxford & 12 & 6 \\
\hline Rutland & 2 & 0 \\
\hline Shropshire & 17 & 8 \\
\hline Somerset & 10 & 2 \\
\hline Southampton & 1 & 3 \\
\hline Stafford & 11 & 1 \\
\hline Suffolk & 7 & 6 \\
\hline Surrey & 2 & 2 \\
\hline Sussex & 4 & 2 \\
\hline Warwick & 8 & 2 \\
\hline Westmorland & 6 & 1 \\
\hline Wiltshire & 12 & 3 \\
\hline Worcester & 3 & 1 \\
\hline York & 80 & 54 \\
\hline
\end{tabular}


CHECKED 20 I Butler

to conform to this category of behavior, the crime bears many of the same earmarks as the acts examined by McIntosh. Suicide is a private act with public consequences: a suicide endangered the spiritual wellbeing of the suicide's community and, particularly if the suicide was male, the financial well-being of his family and his parish (in the event that his family became reliant on the alms of fellow parishioners); it also shattered the social harmony of a community. Suicide also jeopardized the social order by highlighting individual actions carried out without the sanction of any social superior. A community desperate to defend its social hierarchy and protect the peace by prosecuting social misbehaviors might reasonably also show concern for suicide, a significantly more destabilizing act than scolding, backbiting, or gambling. In this respect, as McIntosh demonstrates in her study, women who refused to conform to social expectations may have seemed the more pressing problem. As social miscreants, men transgressed only one hierarchy: the social hierarchy, defined best by property, power, and reputation. Women, on the other hand, transgressed two: the social hierarchy and the gender hierarchy. As a result, even if a man and a woman both carried out the same offense, a woman, who was supposed to be under the good governance of her father or husband, inevitably committed the graver wrong. In those counties where female self-killings were more frequently reported, jurors may have begun to embrace this ideology. Face to face with a woman's distended and watery corpse, jurors in the East Midlands may have judged it a suicide whereas elsewhere a judgment of misadventure would have seemed perfectly appropriate.

\section{Conclusion}

In 1979, Hanawalt formulated the tentative hypothesis that "medieval women like modern ones turned their aggressions toward themselves in suicide rather than to committing homicide" $(1979,123)$. The much greater visibility of women in cases of suicide than of homicide would seem to lend credence to her argument. While medieval literary and oral culture often attributed female suicide to diabolical intervention, a more modern conclusion might be to argue that women were the victims of an overly rigid gender hierarchy. Emile Durkheim would have classified these female self-killers as fatalist suicides, a form of suicide that "derives from excessive regulation, that of persons with futures pitilessly blocked and passions violently choked by oppressive discipline" (Durkheim [1857] 1951, 276). Liu Meng, in her analysis of suicide among women in late twentieth-century rural China, admittedly an even more unbendingly 
patriarchal society, has also turned to oppression as a way of making sense of the high rates of female self-violence. She argues that "suicide is one of the ways for women to rebel against their oppressive status in the society and a real denouncement of the unequal relationship between genders" (Meng 2002, 308). Later medieval England was highly focused on preserving and enforcing traditional hierarchies; in such a repressive environment it is not hard to imagine that women may have been drawn more frequently into suicide as a form of rebellion or merely an escape. Undoubtedly, single women, who usually lived impoverished lives and were often harassed by the courts for their independent natures, may have seen suicide as a way of taking control of their lives. As a complement, it seems clear that jurors were more inclined to report the criminal activity of single women than of wives, thus somewhat falsely inflating the proportions.

Women's participation in self-killing was also distinct. While men were more frequently drawn to dramatic and bloody methods of suicide, women's self-killings were somewhat more domestic in nature, drowning in wells or the river or hanging themselves with their wimples.

Royal indictments of self-killings also lend some insight into the role played by jurors in prosecuting suicide. Stories of self-killing, such as the one with which I began this study, guaranteed that men and women in medieval England knew well the dangers and possible consequences of suicide. While the woman in the tale was fortunate to have had the opportunity to confess and be forgiven her sins before she died, most suicides died without having confessed, their bodies denied a Christian burial, their souls condemned to hell. Jurors could not help but be influenced by these details in their verdicts. It is striking, however, that the specter of the devil, lying in wait to possess vulnerable women and drive them mad, does not seem to have been a common explanation for suicide used by jurors. Rather, from those indictments that do offer insight into jurors' decisions, they drew on a more complex pool of rationalizations that included diabolical temptation but also saw various forms of mental instability, loss of a family member, and even an unruly lifestyle as possible explanations. Perhaps because jurors encountered fewer cases of female suicide, a woman's self-violence was more meaningful. Men's self-killings did not frequently draw strong emotions from jurors; women's, on the other hand, were more likely to elicit extreme responses, ranging from compassion to censure. Nonetheless, the image of women being incapable of violence also played a role in the reporting of suicides. With such inconstant male-female ratios, it seems likely that in some regions jurors did not report all acts of self-killings and often may have been inclined 
CHECKED 22 I Butler

to overlook female self-killings. Elsewhere jurors were more prepared to lay blame, especially when the self-killer was a woman. At the very least, the records suggest that when a jury was confronted with a corpse and forced to determine whether suicide might have come into play, the sex of the dead was an important determinant in its verdict.

\section{Appendix}

The sources for the figures cited in this article are derived from my research in the following manuscript collections and printed sources.

\section{Manuscript Sources}

The National Archives (TNA), Kew, Surrey, UK JUST 1

Bedfordshire $(24,46)$; Berkshire $(36,44)$; Buckinghamshire $(63,55)$; Cambridgeshire $(86,95)$; Cornwall $(111,118)$; Cumberland $(133,135)$; Derby (166, 148); Devonshire (181, 175); Dorset (204, 213); Durham (223); Essex (230, 233, 238, 242, 244, 245); Gloucestershire (278, 274); Hampshire (780, 787); Herefordshire $(302,300 \mathrm{C})$; Hertfordshire $(325,318)$; Huntingdonshire (345, 343); Kent (369, 374); Lancashire (409); Lancaster (436, 437); Leicstershire (461, $455)$; Lincolnshire $(486,480,488)$; Middlesex $(486,538)$; Norfolk $(568,573)$; Northamptonshire $(635,623)$; Northumberland $(653)$; Nottinghamshire $(664$, 683); Oxfordshire (700, 705); Rutland (725); Shropshire (737, 739); Somerset (759); Staffordshire (806); Suffolk (827); Surrey (876, 872); Warwick (951A, 956); Westmorland $(982,986)$; Wiltshire $(996,1005$ PT 2); Worcestershire (1025, 1022); Yorkshire (1043, 1051, 1053, 1060, 1070, 1073, 1078, 1098, 1109, 1101 , $1108)$.

The National Archives (TNA), Kew, Surrey JUST 2, in its entirety.

\section{Print Sources}

Chew, Helena M., and Martin Weinbaum, eds. 1970. The London Eyre of 1244. Vol. 6. Leicester: London Record Society.

Clanchy, M. T., ed. 1973. The Roll and Writ File of the Berkshire Eyre of 1248. Publications of the Selden Society, vol. 90. London: Selden Society.

De Windt, Anne Reiber, and Edwin Brezette De Windt, eds. and trans. 1981. Royal Justice and the Medieval English Countryside: The Huntingdonshire Eyre of 1286, the Ramsey Abbey Banlieu Court of 1287, and the Assizes of 1287-1288, PT 1. Toronto: Pontifical Institute of Mediaeval Studies.

Fowler, George Herbert, ed. 1917. Roll of the Justices in Eyre at Bedford, 1227. Bedfordshire Historical Record Society, vol. 3. Streatley, Bedfordshire. 
S I G N S Autumn 2006 | CHECKED 23

Fowler, George Herbert, ed. 1939. Calendar of the Roll of the Justices on Eyre, 1247. Bedfordshire Historical Record Society, vol. 21. Streatley, Bedfordshire.

Gross, Charles, ed. 1896. Select Cases from the Coroners' Rolls A.D. 1265-1413: With a Brief Account of the History of the Office of Coroner. Publications of the Selden Society, vol. 9. London: Quaritch.

Harding, Alan, ed. 1981. The Roll of the Shropshire Eyre of 1256. Publications of the Selden Society, vol. 96. London: Selden Society.

Hunnisett, Roy F., ed. 1961. Bedfordshire Coroners' Rolls (1265-1380). Bedfordshire Historical Record Society, vol. 41. Streatley: Bedfordshire Historical Record Society.

Hunnisett, Roy F., ed. 1969. Calendar of Nottinghamshire Coroners' Inquests, 1485-1558. Thoroton Society Record Series, vol. 25. Nottingham: Produced for the Thoroton Society by Derry \& Sons.

Meekings, Cecil Anthony Francis, ed. 1961. Crown Pleas of the Wiltshire Eyre, 1249. Devizes: Wiltshire Archaeological and Natural History Society, Records Branch, vol. 16.

Page, William,. ed. 1891. Three Early Assize Rolls for the County of Northumberland. Surtees Sociey, vol. 88. Durham: Published for the Society by Andrens \& Company.

Palmer, William Mortlock, ed. 1930. The Assizes Held at Cambridge, A.D. 1260: Being a Condensed Translation of Assize Roll 82 in the Public Record Office, with an Introduction. Linton: Eagle Printing Works.

Rogers, James E. Thorold, ed. 1891. Oxford City Documents, Financial and Judicial, 1268-1665. Oxford Historical Society, vol. 18. Oxford: Clarendon.

Sharpe, Reginald R., ed. 1913. Calendar of Coroners Rolls of the City of London, A.D. 1300-1378. London: R. Clay \& Sons.

Stenton, Doris Mary, ed. 1926. The Earliest Lincolnshire Assize Rolls, A.D. 1202-1209. Lincoln Record Society, vol. 22.

Stenton, Doris Mary, ed. 1937. Rolls of the Justices in Eyre, Being the Rolls of Pleas and Assizes for Yorkshire in 3 Henry III (1218-1219). Selden Society, vol. 56. London: Quaritch.

Stenton, Doris Mary, ed. 1952. Pleas Before the King or His Justices, 1198-1212. Vol. II, Rolls or Fragments of Rolls from the Years 1198, 1201 and 1202. Selden Society, vol. 67, PT 2.

Summerson, Henry, ed. 1985. Crown Pleas of the Devon Eyre of 1238. Devon and Cornwall Record Society, vol. 28. Torquay: Devonshire.

Weinbaum, Martin, ed. 1976. The London Eyre of 1276. Publications-London Record Society, vol. 12. Leicester: London Record Society.

Department of History, Loyola University, New Orleans 
CHECKED 24 I Butler

References

Amundsen, Darrel M. 1989. "Suicide and Early Christian Values." In Suicide and Euthanasia: Historical and Contemporary Themes, ed. Baruch A. Brody, 77-153. London: Kluwer Academic.

Aquiló y Fúster, Mariano, ed. 1881. Recull de eximplis e miracles, gestes e faules e altres ligendes ordenades per A.B.C., tretes de un manuscrit en pergami del començament del segle $X V$. Barcelona: A. Verdaguer.

Bellamy, John G. 1998. The Criminal Trial in Later Medieval England: Felony before the Courts from Edward I to the Sixteenth Century. Toronto: University of Toronto Press.

Bonger, W. 1916. Criminality and Economic Conditions. Boston: Little, Brown.

Butler, Sara M. 2006. "Degrees of Culpability: Suicide Verdicts, Mercy, and the Jury in Medieval England." Journal of Medieval and Early Modern Studies 36(2):261-88.

Caesarius of Heisterbach. 1901. Die Fragmente der Libri VIII Miraculorum des Caesarius von Heisterbach [A fragment of book eight of the miracles of Caesarius of Heisterbach], ed. Aloys Mesiter. Römische Quartalschrift für christliche Alterthumskunde und für Kirchengeschichte, vol. 14. Supplementheft.

Cam, Helen M., ed. 1968. The Eyre of London: 14 Edward II, A.D. 1321. Publications of the Selden Society, vols. 85 and 86. London: Quaritch.

Durkheim, Emile. (1897) 1951. Suicide: A Study in Sociology. Ed. George Simpson. Trans. John A. Spaulding and George Simpson. New York: Free Press.

Ellis, Deborah S. 1998. "Domesticating the Spanish Inquisition.” In Violence against Women in Medieval Texts, ed. Anna Roberts, 195-209. Gainesville: University Press of Florida.

Farmer, Sharon. 1999. "'It Is Not Good That [Wo] man Should be Alone': Elite Responses to Singlewomen in High Medieval Paris." In Singlewomen in the European Past, 1250-1800, ed. Judith M. Bennett and Amy M. Froide, 82-105. Philadelphia: University of Pennsylvania Press.

- 2002. Surviving Poverty in Medieval Paris: Gender, Ideology, and the Daily Lives of the Poor. Ithaca, NY: Cornell University Press.

Frugoni, Chiara. 1992. "The Imagined Woman." Trans. Clarissa Botsford. In $A$ History of Women: Silences of the Middle Ages, ed. Christiane Klapisch-Zuber, 336-422. Cambridge, MA: Belknap.

Garay, Kathleen E. 1979. "Women and Crime in Later Mediaeval England: An Examination of the Evidence of the Courts of Gaol Delivery, 1388 to 1409." Florilegium 1:87-109.

Gering, Hugo, ed. 1882-83. Islendzk Aventyri: Isländische Legenden, Novellen und Märchen. Halle A. S.: Buchhandlung des Waisenhauses.

Green, Thomas Andrew. 1985. Verdict according to Conscience: Perspectives on the English Criminal Trial Jury, 1200-1800. Chicago: University of Chicago Press.

Gregg, Joan Young, ed. 1997. Devils, Women, and Jews: Reflections of the Other in Medieval Sermon Stories. Albany: State University of New York Press. 
Hair, Paul Edward Hedley. 1970. "A Note on the Incidence of Tudor Suicide." Local Population Studies 5:36-43.

—. 1971. "Deaths from Violence in England: A Tentative Secular Survey." Population Studies 25(1):5-24.

Halliday, Robert. 1996. "Wayside Graves and Crossroads Burials." Proceedings of the Cambridge Antiquarian Society 84:113-18.

Hanawalt, Barbara A. 1976. "The Female Felon in Fourteenth-Century England." In Women in Medieval Society, ed. Susan Mosher Stuard, 125-40. Philadelphia: University of Pennsylvania Press.

q12 Crime and Conflict in English Communities, 1300-1348. Cambridge, MA: Harvard University Press.

Harding, Alan, ed. 1981. The Roll of the Shropshire Eyre of 1256. Publications of the Selden Society, vol. 96. London: Selden Society.

Herbert, J. A. 1910. Catalogue of Romances in the Department of Manuscripts in the British Museum. Vol. 3. London: Trustees of the British Museum.

Hunnisett, Roy F., ed. 1961. Bedfordshire Coroners' Rolls (1265-1380). Bedfordshire Historical Record Society, vol. 41. Streatley, UK: Bedfordshire Historical Record Society.

—, ed. 1969. Calendar of Nottinghamshire Coroners' Inquests, 1485-1558. Thoroton Society Record Series, vol. 25. Nottingham: Produced for the Thoroton Society by Derry \& Sons.

Karras, Ruth Mazo. 1999. "Sex and the Singlewoman." In Singlewomen in the European Past, 1250-1800, ed. Judith M. Bennett and Amy M. Froide, 127-45. Philadelphia: University of Pennsylvania Press.

Klapper, Joseph, ed. 1914. Erzählungen des Mittelalters in deutscher Übersetzung und lateinischem Urtext. Wort und Brauch, vol. 12. Breslau: M. and H. Marcus.

MacDonald, Michael, and Terence R. Murphy. 1990. Sleepless Souls: Suicide in Early Modern England. Oxford: Oxford University Press.

McIntosh, Marjorie Keniston. 1998. Controlling Misbehavior in England, 1370-1600. Cambridge: Cambridge University Press.

McLane, Bernard William. 1988. "Juror Attitudes towards Local Disorder: The Evidence of the 1328 Lincolnshire Trailbaston Proceedings." In Twelve Good Men and True: The Criminal Trial Jury in England, 1200-1800, ed. J. S. Cockburn and Thomas A. Green, 36-64. Princeton, NJ: Princeton University Press.

Meng, Liu. 2002. "Rebellion and Revenge: The Meaning of Suicide of Women in Rural China." International Journal of Social Welfare 11(4):300-309.

Midelfort, H. C. Erik. 1999. A History of Madness in Sixteenth-Century Germany. Stanford, CA: Stanford University Press.

Murray, Alexander. 1998. Suicide in the Middle Ages. Vol. 1, The Violent against Themselves. Oxford: Oxford University Press.

Musson, Anthony. 1996. Public Order and Law Enforcement: The Local Administration of Criminal Justice, 1294-1350. Woodbridge, UK: Boydell. 
CHECKED 26 I Butler

Newman, Barbara. 1998. "Possessed by the Spirit: Devout Women, Demoniacs, and the Apostolic Life in the Thirteenth Century." Speculum 73(3):733-70.

Pollak, Otto. 1950. The Criminality of Women. Philadelphia: University of Pennsylvania Press.

Riddle, John M. 1997. Eve's Herbs: A History of Contraception and Abortion in the West. Cambridge: Cambridge University Press.

Rieder, Paula M. 2002. "Insecure Borders: Symbols of Clerical Privilege and Gender Ambiguity in the Liturgy of Churching." In The Material Culture of Sex, Procreation, and Marriage in Premodern Europe, ed. Anne L. McClanan and Karen Rosoff Encarnación, 93-113. New York: Palgrave.

Seabourne, Gwen, and Alice Seabourne. 2000. "The Law on Suicide in Medieval England." Journal of Legal History 21(1):21-48.

Shinners, John, ed. 1997. Medieval Popular Religion, 1000-1500: A Reader. Peterborough: Broadview.

Strange, Josephus, ed. 1851. Caesarii Heisterbacensis Monachi ordinis Cisterciensis Dialogus Miraculorum [Dialogue on miracles of Caesarius of Heisterback, a monk of the Cistercian Order]. Cologne: Sumptibus J. M. Heberle.

Summerson, Henry. 2000. "Suicide and the Fear of the Gallows." Journal of Legal History 21(1):49-56. 


\section{QUERIES TO THE AUTHOR}

1. Au: In footnote 1 , does "I" refer to vol. 1? And, as to the Herbert 1910 references, to what do the numbers refer $(586$, no. 60$)$ ? Some clarification at first mention would be helpful to the reader.

2. Au: Is 1960 the correct date? 1961 and 1969 are shown in the reference list.

3. Au: What is " 2.33 "? Please clarify.

4. Au: Near the end of footnote 19 , in the entry "TNA JUST $2 / 215$, mms. 3 and 4 (Yorkshire), Alice ...," is "mms." the usual format used for such archival entries? If not, may we use the standard abbreviation "MSS" for plural manuscripts? And elsewhere in the text "MS" for singular manuscript?

5. Au: At the end of footnote 23 (and in similar instances), is "PT" the usual format for archival citations, or would "pt." be appropriate?

6. Au: Please provide a title for the table (I've made up one for the interim).

7. Au: Can numbers be put in numerical order, or stet as written?

8. Au: Please provide publisher and city here and in other similar citations. Would "Streatley: Bedfordshire Historical Record Society" be correct for the Fowler citations, as shown with other citations below?

9. Au: Is this vol. 16 of Crown Pleas? If not, to what does it apply?

10. Au: Publisher and city?

11. Au: City of publication and publisher? Also, does "vol. 14" apply to the given title Die Fragmente...? 
12. Au: What is the date for the second Halliday citation?

13. Au: Is Wort und Brauch a subtitle, or is it the title of vol. 12?

14. Au: Is Murray the editor for vol. 1? 
Please return this form even if no reprints are ordered.

\section{NO REPRINTS DESIRED}

\section{PLEASE CHOOSE ONE OF THE FOLLOWING OPTIONS:}

\section{FREE SUBSCRIPTION OR RENEWAL FOR ONE YEAR $\square 10$ COMPLIMENTARY COPIES OF THE ISSUE}

AUTHORS: REPRINT ORDER MUST BE RECEIVED PRIOR TO PRINTING OF JOURNAL ISSUE. Please return this form immediately even if no reprints are desired. Reprints ordered through an institution will not be processed without a purchase order number. Payment by check, Money Order, Visa, or MasterCard is required with all orders not accompanied by an institutional purchase order or purchase order number. Make checks and purchase orders payable to The University of Chicago Press.

TO BE COMPLETED BY AUTHOR:

Signs Vol_____ No ______ Month

Author(s): No of pages in article

Title of Article:

\section{REPR I N T C H AR G S (please compute)}

Quantity

Covers

Subtotal

GST ( $7 \%$ for Canadian destinations only)

Non-U.S. and non-Canada shipping

(Non-U.S. orders add $45 \%$ to subtotal)

TOTAL DUE (US \$)

Prices include shipping for U.S. and Canadian orders. Non-U.S and non-Canadian orders are shipped via Airmail at an additional cost of $45 \%$ of the total printing charge.

SHIPPING INSTRUCTIONS

BILLING INSTRUCTIONS (Institutional Orders Only)

Name Institution

City

State Zip

Street

Country

City State Zip

*Phone

* Please include a phone number in case we need to contact you about your order

Country

MAKE CHECKS AND PURCHASE ORDERS PAYABLE TO: The University of Chicago Press.

All orders must be accompanied by one of the three payment options (purchase order, check/money order, or Visa/MasterCard):



Cardmember name as it appears on card (please print clearly)

Card Number Expiration Date

Signature Phone

3) Institutional Purchase Order No. 


\section{Signs}

Rutgers University

Room 8, Voorhees Chapel

5 Chapel Way

Douglass College

New Brunswick, NJ 08901

DO NOT DELAY ORDERING YOUR REPRINTS: Orders must be in hand before the issue goes to press.

FORMAT: Offprints are printed exactly as articles appear in the journal, but without any backing material. They are trimmed on all sides and saddle-stitched. Covers are printed on white stock and include article title, author's name, copyright information, and issue date.

DELIVERY AND INVOICES: Reprints are shipped 2-4 weeks after publication of the Journal. Invoices are mailed at the time of shipment. For all orders charged to institutions, an official Purchase Order must be in hand before the reprint shipment can be released. Reprint orders payable by individuals must be accompanied by advance payment by check, Money Order, Visa, or MasterCard. In case of non-U.S. purchases, this payment must be made in the form of a check payable in U.S. currency via an American bank. Terms are net 30 days.

\section{REPRINT}

\section{PRICE LIST}

\begin{tabular}{|c|c|c|c|c|c|c|c|c|}
\hline \multicolumn{9}{|c|}{ Number of pages } \\
\hline & $1-4$ & $5-8$ & $9-12$ & $13-16$ & $17-20$ & $21-24$ & $\begin{array}{l}\text { add'l } 4 \\
\text { pages }\end{array}$ & $\begin{array}{c}\text { COVER } \\
\mathrm{S}\end{array}$ \\
\hline 25 & $\$ 26$ & $\$ 30$ & $\$ 35$ & $\$ 41$ & $\$ 46$ & $\$ 50$ & $\$ 6$ & $\$ 14.00$ \\
\hline 50 & $\$ 34$ & $\$ 40$ & $\$ 46$ & $\$ 53$ & $\$ 59$ & $\$ 66$ & $\$ 7$ & $\$ 18.00$ \\
\hline 100 & $\$ 52$ & $\$ 65$ & $\$ 77$ & $\$ 91$ & $\$ 103$ & $\$ 116$ & $\$ 13$ & $\$ 35.00$ \\
\hline 150 & $\$ 67$ & $\$ 86$ & $\$ 104$ & $\$ 125$ & $\$ 143$ & $\$ 163$ & $\$ 19$ & $\$ 53.00$ \\
\hline 200 & $\$ 87$ & $\$ 111$ & $\$ 135$ & $\$ 162$ & $\$ 174$ & $\$ 202$ & $\$ 25$ & $\$ 70.00$ \\
\hline 250 & $\$ 116$ & $\$ 147$ & $\$ 177$ & $\$ 211$ & $\$ 241$ & $\$ 276$ & $\$ 31$ & $\$ 88.00$ \\
\hline 300 & $\$ 138$ & $\$ 176$ & $\$ 212$ & $\$ 253$ & $\$ 289$ & $\$ 330$ & $\$ 37$ & $\$ 105.00$ \\
\hline 350 & $\$ 161$ & $\$ 204$ & $\$ 243$ & $\$ 294$ & $\$ 336$ & $\$ 373$ & $\$ 43$ & $\$ 123.00$ \\
\hline 400 & $\$ 183$ & $\$ 233$ & $\$ 329$ & $\$ 337$ & $\$ 385$ & $\$ 440$ & $\$ 49$ & $\$ 140.00$ \\
\hline
\end{tabular}

